\begin{tabular}{c} 
Volume and Issues Obtainable at Center for Sustainability Research and Consultancy \\
Journal of Accounting and Finance in Emerging Economies \\
ISSN: 2519-0318 ISSN (E) 2518-8488 \\
Volume 7: Issue 1 March 2021 \\
CSRC \\
Journal homepage: $\underline{\text { ww.publishing.globalcsrc.org/jafee }}$ \\
\hline
\end{tabular}

\title{
Current Issues and Problems about the Quality Improvement Faced by Management in Higher Educational Institutions
}

\author{
${ }^{1}$ Gulshan Fatima Alvi, ${ }^{2}$ Mahwish Safder, ${ }^{3}$ Musarrat Habib \\ ${ }^{1}$ Assistant Professor Lahore Leads University Lahore, Pakistan, gulshan_fatima_alvi@yahoo.com \\ ${ }^{2}$ Assistant Professor Lahore Leads University Lahore, Pakistan, mahwishsafder@ gmail.com \\ ${ }^{3}$ Senior Teacher Lahore College of Arts \& Sciences (LACAS), Lahore, Pakistan, \\ javaidmusarrat@gmail.com
}

\begin{tabular}{l} 
ARTICLE DETAILS \\
\hline History \\
Revised format: January 2021 \\
Available Online: March \\
2021
\end{tabular}

Keywords

Higher education

management, quality, higher education commission.

JEL Classification:

$M 0, M 1$

\section{ABSTRACT}

Higher education plays a vital role in the community and the universities are the backbone of the higher education system. Management is an important part of higher education; to survive. The administration of higher education is considered essential to achieving economic progress, political stability and peace. . In this research the researcher found the current challenges facing administrators to maintain the status of higher education in public and private universities. The objectives of the study were to identify the issues and problems faced by management to maintain the quality of higher education at the university level, to identify the importance of quality in the management of higher education, to help in updating our universities for best meeting future demands, and to suggest the possible solutions of current issues and problems to improve the quality of higher education management. The qualitative approach was used as a research methodology in this study. Five universities from Lahore were selected for observing the current issues and problems about the quality of higher education management. Data were collected through interviews. The vicechancellors, registrars, controllers, treasurers and heads of human resource departments of these universities were selected for interviews. Interview protocol was used for the collection of data. The results were analyzed with the help of initial codes and broad categories It was concluded that it is necessary for the quality of higher education, to boost up higher education management. It was also determined that all the universities management almost is trying to improve their abilities towards academic matters under the umbrella of Higher Education Commission(HEC). The researchers recommended that by removing the current issues and problems concerned to the management in the universities should be mobilizing financial, technical, human and social resources for enhancing the quality of education, and for facilitating the reform process initiated within these institutions.

(C) 2020 The authors, under a Creative Commons AttributionNonCommercial 4.0 


\section{OPEN ACCESS}

Corresponding author's email address: gulshan_fatima_alvi@yahoo.com

Recommended citation: Alvi, G. F., Safder, M. \& Habib, M. (2021). Current Issues and Problems about the Quality Improvement Faced by Management in Higher Educational Institutions. Journal of Accounting and Finance in Emerging Economies, 7(1), 1-8

\section{Introduction}

Higher education management is facing major challenges and difficulties related to funding, equitable access to and in-education courses, improved human resource development, skills-based training, development and quality assurance in teaching, research and services, program alignment, graduate employment, co-ordination and co-operation agreements. At the same time, higher education is challenged by new technological opportunities that improve how information can be produced, managed, distributed, accessed and controlled (Allui \& Sahni, 2016).

To Manage the Higher education is also in front of the challenge in Pakistan that has an impact on its quality and quantity. If there is need to compare the number of students in higher education at the time of independence, with the number of students enrolled now in our universities and colleges, we see an incredible increase. Unluckily management is not capable to furnish the growing demands of students. Until the 1990s we were unrelenting to the inadequate numeral of public universities and colleges, accountable for teaching higher education. In mid 90s universities in the private sector were being provided with licenses. This observable fact provided a new trend to higher education in Pakistan (Rehman \& Khan 2011). Ever since then we have made some progress quantitatively but not qualitatively. But still, the number of higher education institutions and their quality is far from reasonable. During the last fifteen years or so, Pakistan and other South Asian countries have been giving great attention to maintaining the quality of higher education management (Haider, 2008).

The justification of this study is focused on current issues and problems about quality improvement faced by the management of higher educational institutions.

\section{Literature Review}

Higher education today is recognized as a major investment and is essential for the economic and social development of a country. Institutions of higher learning have a great responsibility to equip people with the new knowledge and skills needed in government, business and other fields (Ekene \& Suleh, 2015). It is the general and specific command and control over the dealings of educational organization and gives effect to the decisions of all the establishment of it. Managers of higher education institutions have many complex responsibilities. They are expected to mobilize, categorize and maximize the human, physical and financial resources to achieve educational objectives. They are charged with the responsibility of motivating, evaluating, and coordinating the efforts of personnel engaged in various tasks that are tied together by a complex division of labor and a system of authority. They are expected to appraise the weaknesses of their organizations and to propose and carry out changes and innovations to eliminate these weaknesses. (George \& Jones, 2014).

Quality in higher education is a multi-faceted concept, which includes all activities related to the activities that are part of the learning life. Management has a significant impact on the quality of higher education, the provision of quality assurance mechanisms, performance indicators, educational review, strategic planning and management, accountability and the quality of university teaching, research and student support services. (Isani \& Virk, 2003).

Curaj, Deca and Pricopie (2019) explained that without the resources available for the expansion of 
universities, they could not achieve the best results without proper management. Further they also began to realize that this is due to poor quality of management. Development of higher education is also dependent on it (Ahmad, Rehman, Ali, Khan \& Khan, 2014).

Higher Education Management encourages institutions to pursue continuous quality development and build on their existing teaching and research capacity, promote diversity of provision and effective partnerships, and encourage all universities to introduce student evaluation practices so that continuous feedback on teacher performance can be achieved (Hénard \& Roseveare, 2012).

HEC was established in September 2002 to direct higher education policy and assist universities and graduate institutions in the pursuit of higher education in the field of higher, public and private education. Its purpose is to work with administrators to improve the quality and quantity of higher education and to assist in social and economic development in Pakistan. The Higher Education Commission encourages institutional administration to continue to improve quality and build on their existing teaching and research capacity, promote diversity of provision and beneficial partnerships, and encourage all universities to introduce student assessment so that continuous feedback on teacher performance is available (Mahmood, 2016).

The administration of higher education in Pakistan is plagued by many problems. The administration of institutions of higher learning has not been able to achieve the ultimate goal of higher education, which is to produce people with good morals and intellectual and academic ability that can develop rational thinking and contribute effectively to the industrial, economic, technological and social development of the country (Jahangir, 2008). The most pressing issues of higher education in Pakistan include, among other things, a flawed institutional system with flaws in inefficiency and inefficiency in the construction and delivery of services, inefficiency and waste, inefficiency and slow productivity in all aspects of the education sector (Shaikh, 2021).

\section{Objectives of the Study}

The objectives of this study were following.

a) To identify the issues and problems faced by the university management to sustain the quality of higher education at the university level.

b) To recognize the significance of quality in higher education management.

c) To help in updating our universities for best meeting future demands.

d) To suggest the possible solutions to current issues and problems to improve the quality of higher education management.

\section{Research Questions}

1. What are the problems and issues which are being faced by the universities management to get the standardized quality of higher education?

2. How managers are working to enhance the quality of higher education?

3. What are the possible solutions to overcome these problems and Issues which are the hurdles for the management towards the quality improvement of higher education?

\section{Research Methodology \& Procedure}

The study was descriptive and was focused on the survey method. The design of the study was crosssectional.

\subsection{Population}

The vice-chancellors, registrars, controllers, treasurers and heads of human resource departments of all the chartered universities of the district Lahore established as population of the study. 


\section{Table 1:}

\begin{tabular}{lccc}
\hline List of Universities & Type & Specialization & Year Established \\
\hline University of the Punjab Lahore & Public & General & 1882 \\
University of Central Punjab, Lahore & Private & General & 1999 \\
Government College University, Lahore & Public & General & 2002 \\
University of Education, Lahore & Public & General & 2002 \\
Lahore College for Women University, Lahore & Public & General & 2002 \\
Hajvery University, Lahore & Private & General & 2002 \\
University of Lahore, Lahore & Private & General & 2002 \\
Minhaj University, Lahore & Private & General & 2003 \\
Beacon house National University, Lahore & Private & General & 2003 \\
University of Central Punjab & Private & General & 2002 \\
\hline
\end{tabular}

\subsection{Participants}

The Purposive sampling method was used for this research study which is one type of non-random sampling method.

There are ten general charted educational universities in Lahore. Out of these universities, four are public sector universities while six are private sector universities.

The researcher decided to select University of the Punjab, Lahore as the oldest university, Government College University and Lahore College for Women University, as representative of upgraded Government colleges, the University of Education as the newly established public sector university and the University of Lahore, as representative of newly established private sector university for finding out comparative point of view with the public sector universities. In this way following five universities were included in the sample of the study.

Table 2: List of Selected Universities

\begin{aligned} \hline S. No. & Name of University \\ \hline 1. & University of the Punjab, Lahore \\ 2. & The University of Lahore, Lahore \\ 3. & University of Education, Lahore \\ 4. & Lahore College for Women University, Lahore \\ 5. & Government College University, Lahore \end{aligned}

The relevant persons of the university who could provide the requisite information for the study, included Vice-Chancellors, Registrars / Director Administration, Treasurers/ Director of Finance, Controllers and Director of Human Resources. The details of the sample were given in the following table:

Table 3: Distributions of Sample

\begin{tabular}{lcccccc}
\hline Respondent / University & PU & GCU & LCWU & EU & LU & Total \\
\hline Vice-Chancellor & 1 & 1 & 1 & 1 & 1 & 5 \\
Controller of Examinations & 1 & 1 & 1 & 1 & 1 & 5 \\
Treasurer/Director Finance & 1 & 1 & 1 & 1 & 1 & 5 \\
Registrar/Director Administration & 1 & 1 & 1 & 1 & 1 & 5 \\
Director Human Resource & 1 & 1 & 1 & 1 & 1 & 5 \\
Total & 5 & 5 & 5 & 5 & 5 & 25 \\
\hline
\end{tabular}




\subsection{Research Instruments}

As the study was a survey in nature therefore semi-structured interviews were used for data collection. Researcher developed 5 interview schedules based on related literature.

i. First interview schedules were administrated to the Vice-chancellors of the selected universities.

ii. The Second interview schedule was administrated to the Registrars of the selected universities.

iii. The Third interview schedule was administrated to the Controllers of the examinations of the selected universities.

iv. The Fourth interview schedule was administrated to the Treasurers of the selected universities.

v. The Fifth interview schedule was administrated to the Human Resource Department concerned persons of the selected universities.

\subsection{Validation of Instruments}

The Validity of the research instruments has referred to the appropriateness, meaningfulness, correctness and usefulness of the inferences which a researcher makes. These inferences have been considered during the selection and design of the instruments. Interview questions were validated by experts of related field.

\subsection{Data Collection}

The researcher collected the data from the respondents personally. Researcher visited the selected universities. The distribution of sample respondents was as under.

Table 4: Distribution of Sample Respondents

\begin{tabular}{clcc}
\hline Sr. \#. & Name of Universities Selected & $\begin{array}{l}\text { Expected No of } \\
\text { Respondent }\end{array}$ & $\begin{array}{l}\text { No. of } \\
\text { Respondent }\end{array}$ \\
\hline 1. & University of Punjab & 5 & 5 \\
2. & The University of Lahore & 5 & 5 \\
3. & University of Education & 5 & 5 \\
4. & Lahore College for Women University & 5 & 4 \\
5. & Government College University & 5 & 3 \\
& Total & $\mathbf{2 5}$ & $\mathbf{2 2}$ \\
\hline
\end{tabular}

Some private universities are playing a key role in enhancing the literacy rate and also trying to contribute for the young generation's better future, but ministry of education does not care about their due financial resources and during taking the important decisions about curriculum planning, etc.

\subsection{Data Analysis}

For gathering information related to the current issues and problems about quality improvement faced by the management in universities, the data were analyzed through coding.

Broad Categories

Current problems and issues about the quality improvement faced by management in general public sector universities.
Not standardized GPD for the higher education

\section{Initial Codes}

Not up to the mark I.T facilities.

Not sufficient funds for the research projects with collaboration of the world ranking universities. 
Not sum up of progressive work of all the universities under one standard charter

Not contributory worth of the research in the field of education.

Not sharing of all the research projects among universities.

Not cooperative behavior of subordinates and faculty with the management.

Not transparent dealings of the university affairs because of political influence.

Not share in the GDP allocated by the national budget

Not well- equipped laboratories

Not up to the mark I.T facilities

Not sufficient funds for the research projects with the collaboration

Current problems and issues about the of the world ranking universities quality improvement faced by management in private sector universities

Not sum up of progressive work of all the universities under one standard charter.

Not contributory worth of the research papers in the field of education.

Not sharing of all the research projects among universities.

Not active role of quality enhancement cell in private universities as compare to government universities.

\section{Conclusions}

Higher education management of all the universities is trying to promote their quality level. They are accommodating and facilitating the teachers to promote their level of knowledge and expertise through seminars workshop and other helping symposiums, but still there are many issues and problems which they are facing.

1- As a developing country, unfortunately, Pakistan's total GDP for higher education is only $2 \%$. There is also a huge difference between allocated GDP and sought GDP which is spent on educational operations.

2- $\quad$ Higher education management is trying to make use of all the possible available resources for grooming the educational working, at its divisions and campuses but they cannot sum up all the progressive working under one standard charter. That is why we cannot compete with the international era.

3- Some universities are doing their tasks vastly as compare to others. Especially private sector universities are claiming that government cannot give them due to funds.

4- $\quad$ Our public sector universities have some opportunities for their students to explore relevant fields for their practical exposure/knowledge and as well as their future development but many private sector universities are found no powerful arrangement for said issues.

5- All universities are working in the field of research at their own pace and according to their own 
resources but they do not share their achievement.

6- Collaborations with other international universities are much effective and beneficial for enhancing the quality research of projects. But many research projects are still pending due to lack of financial and human resources.

7- Judgment or performance reviewing of the subordinates is the step towards the improvement of the quality of processes, procedures and practices in the academic department of the university but faculty members and other subordinates are reluctant to do the relevant jobs. For instance, the quality enhancement cell is almost working in all the universities under the command of HEC and the Program Quality Assurance Report (PQAR) is distributing among the teachers for selfassessment. But faculty members do not respond quickly so relative actions also become late.

8- Information Technology is enlightening experience and the exchange grounded in research added to the resources of the participants. Under the project of the universities computerization and networking science laboratories and libraries have been strengthened and new programs in the discipline of science and technology have been initiated but as a developing country, we are still far behind from global networking. One more trend, Europe and especially Japan lead the way is $\mathrm{m}$-commerce, which is mobile or wireless commerce. Increasingly, educationists can commune without computers by using wireless devices.

9- Political influences have a great impact on all the matters especially on the budget which is given to higher education management. Under these circumstances, many managerial decisions are rolled back or deviated to accommodate their "unnecessary projects". If management may want to take an innovative step for quality betterment then they have to face many inquiries and wait for the approval of UGC and other commanding authorities.

\section{Suggestions}

Management of higher education is a very important factor in the growth and prosperity of a nation. It provides the power and resilience to enable people to respond to the changing needs of the hour. Education is the lifeblood of all national endeavors. It has the power to change people's lives for the better. We cannot build a stable and prosperous nation without the proper framework for the administration of higher education, which is the basis for the health and vitality of higher education; therefore the priority can be given to the management of higher education through the appropriate growth of higher education institutions.

Higher education management requires imparting vision, initiating change, and making difficult decisions. To handle these demands, some innovative steps will have to take.

1- No doubt the defense of the country is much necessary but the education is the most necessary part of the country but our GDP for the defense is $20 \%$ and GDP for higher education is only $2 \%$ so higher authorities will have to think over it because without education no nation can meet the modern challenges.

2- Higher education commission has to set some standard charter for summing up the progressive work of all the universities and they also will have to coop with one another to keep with time.

3- The Government will have to give some attention to those private universities who are doing their best but their resources are short no doubt they are taking a huge amount in the form of tuition fee from students but still, they are unable for the research projects and collaborating tasks with the international world ranking universities.

4- No active quality enhancement cell is working in the private sector. .HEC may have to give some attention to the private sector and authorities may have some provision for laboratories, equipment and scientific material in private sector and if they have their own resources so it may impose to take these provisions. 
5- When an adequate percentage of GDP will be given to higher education management, ultimately their resources will be increased and the management information system will be capable to meet the requirement of the global village.

6- Higher education is the pillar of the nations and transparency of its management is the sign of its quality so Political influences and other unnecessary hurdles may have to remove by higher authorities.

\section{References}

Ahmad, I., Ur Rehman, K., Ali, A., Khan, I., \& Khan, F. (2014). Critical Analysis of the Problems of Education in Pakistan: Possible Solutions. International Journal Of Evaluation And Research In Education (IJERE), 3(2). doi: 10.11591/ijere.v3i2.1805

Allui, A., \& Sahni, J. (2016). Strategic Human Resource Management in Higher Education Institutions: Empirical Evidence from Saudi. Procedia - Social And Behavioral Sciences, 235, 361-371. doi: 10.1016/j.sbspro.2016.11.044

Curaj, A., Deca, L., \& Pricopie, R. (2019). EUROPEAN HIGHER EDUCATION AREA (pp. 1-727). Switzerland: Springer International Publishing AG.

Ekene, O., \& Suleh, E. (2015). Role of Institutions of Higher Learning in Enhancing Sustainable Development in Kenya. Journal Of Education And Practice, 6(16), 91-102.

George, J., \& Jones, G. (2014). Understanding and Managing Organizational Behavior. Pearson Education UK.

Hénard, F., \& Roseveare, D. (2012). Fostering Quality Teaching in Higher Education: Policies and Practices (pp. 1-54). Institutional Management in Higher Education.

Hommadi, A.H. (1987). University Administration in Developing Countries. India.

Haider, S. Z. (2008). Challenges in Higher Education. SpeciaAreference to Pakistan and South Asian Developing Countries. Bahawalpur: The Islamic University of Bahawalpur, Pakistan.

Isani, U. A., \& Virk, M. L. (2003). Higher education in Pakistan: A historical and futuristic perspective. Islamabad: National Book Foundation..

Jahangir, K. (2008). Management of higher education reforms in Pakistan: An implementation perspective. Pakistan, Islamabad: National University of Modern Languages Press.

Kupriyanova V., Estermann T., Sabic N. (2018) Efficiency of Universities: Drivers, Enablers and Limitations. In: Curaj A., Deca L., Pricopie R. (eds) European Higher Education Area: The Impact of Past and Future Policies. Springer, Cham. https://doi.org/10.1007/978-3-31977407-7_36.

Rehman H. and Khan N.(2011) "The flaws in Pakistan's Education System", Abasyn Journal of Social Sciences, 4(1).

Shaikh, A. (2021). Economic Survey of Pakistan (pp. 1-503). Islamabad: Economic Adviser's Wing, Finance Division Government of Pakistan, Islamabad.

Tzvetelin. (2006). Quality Management in Higher Education. 1. 1-7. 